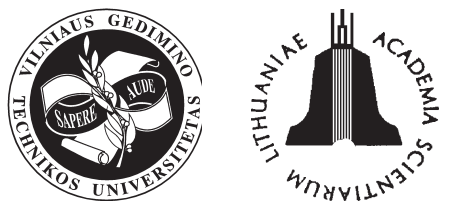

\title{
THE ANALYSIS OF ROAD INFRASTRUCTURE DEVELOPMENT FINANCING IN LITHUANIA
}

\author{
Olga Lingaitienė \\ Vilnius Gediminas Technical University, Plytinès g. 27, LT-10105 Vilnius, Lithuania \\ Dept of Transport Management, Faculty of Transport Engineering \\ E-mail:private14@takas.lt
}

Received 3 November 2005; accepted 4 January 2006

\begin{abstract}
The article describes major problems associated with the development of the Lithuanian roads, the priority areas and distribution of investments. The analysis performed and the calculations of investments into roads made for the last two years and the current year as well as graphical expression of the dynamics are presented and the conclusions are given.
\end{abstract}

Keywords: financing, investments, distribution, transport, roads.

\section{Introduction}

Well-run and effective transport is not only the service creating high value, but also the necessary precondition of the successful development of other fields of economy and of the quality of human well-being. Road infrastructure is one of the fundamental factors predetermining the efficiency of transport activities.

However, as any other economic activity, the creation of transport infrastructure employs resources: land, capital, human. As market relations function, the resources distribute effectively. Nevertheless, today road transport infrastructure is not provided on the market and its funding is defined not by the decisions of market mechanism, but by those of economic policy.

So far, the creation of road infrastructure in Lithuania has been financed from the state budget according to the Programme of Road Maintenance and Development and from municipality budgets. When Lithuania joined the European Union and adopted the acquis (i.e. legal regulations, agreements, principles, resolutions and practices) related to the financing of road networks, this problem required new approaches taking into account the following issues:

$>$ a so-called road tax paid depending on turnover and making about a half of the income of the Lithuanian Road Development Programme had to be abolished according to the EU laws and for economic considerations. In this situation some other sources of financing had to be sought;

$>\quad$ the duties for fuels, making another considerable part of the Programme income, have been increased and are going to grow further in the near future to harmonize the duties according to the standards adopted in the EU;

$>$ now, a directive supplementing the Directive 1999/62/EB 'on charging heavy-weight freight transport facilities for using a particular infrastructure', which strongly emphasizes the principle of financing road development stating that 'the user pays', is being discussed in the EU states;

$>\quad$ the practices of road development financing in the EU states vary considerably, however, the principle of mixed financing (with only the proportion of particular sources ranging to some extent) which is based on the finances obtained from payments for the use of infrastructure and taxes is used everywhere.

\section{Review of the condition of a road net}

The essential indicators of road condition are the evenness, strength, the depth of ruts and the ratio of grip of road. The Lithuanian roads are slightly more even than the roads in Estonia and Latvia [1], but the evenness of the Lithuanian trunk-roads is worse than the evenness of the Finnish roads of the lowest class. To be precise, at present the situation of roads is little by little improving.

In Lithuania transport is an important part of economic and social infrastructure and one of the 
priority fields of economics. Transport has a direct influence on the economic growth of the country via international and inner trade as well as tourism. Comparing with 1994, the intensity of traffic on the Lithuanian roads has increased by $20 \%$, the intensity of international traffic - by $70 \%$. Therefore, with the purpose of assuring unrestricted traffic of goods, services, labour force and capital between Lithuania and other countries, it is necessary to guarantee that the main Lithuanian roads would comply with or at least come up close to the road standards set by the European Union.

At the given moment the length of the Lithuanian road net of national importance is $21345 \mathrm{~km}$, including trunk-roads $-1734 \mathrm{~km}$, country roads $-4878 \mathrm{~km}$, regional - $14733 \mathrm{~km}$; roads with improved covering (asphalt - concrete cement - concrete) - $12519 \mathrm{~km}$ (59\%), gravelled roads - $8706 \mathrm{~km}(41 \%)$ [2]. Roads of national importance make approximately $80 \%$ of all transported loadings. Road net of local importance makes $59149 \mathrm{~km}$.

As Lithuania is integrating into the European Union, roads making $1628 \mathrm{~km}$ are attributed to the European road net, $839 \mathrm{~km}$ of which are the transport corridors of the whole Europe (according to the Crete Agreement). During last 10 years the strength of trunk-roads and country roads has decreased by approximately $12 \%$. Moreover, at the time of Lithuanian integration into the European Union, the maximal legal thrust since 1997 has been increased from 10 to 11,5 tons for axle. It adds concern to our road-menders as the coverings of some roads are not estimated for such thrust and additional funds are to be allocated for strengthening those coverings.

A road net of national importance is not equally developed - in some districts the net of asphalted roads makes $51 \%$ (Siauliai), while the average percentage of the asphalted road net of the country makes $59 \%$.

According to the thorough analysis of the Lithuanian road net of national importance [1], the present funding and funding prospects, the following order of priority of handling and development of a road net has been set:

$>$ The development of international roads. The importance of Lithuania as the country of transit should increase, therefore those roads are to be modernized.

$>$ Handling of roads and bridges. This is regular handling of road elements: strewing with sand and salt mix in winter, snow removal, patching up of bumps and clefts, clearing of trenches, aligning of gravelled roads and roadsides, etc. This will remain the priority activity.

$>$ Handling of road covering and bridge repair. Further wear out of road covering would threaten their condition, therefore it is necessary to increase the scope of repair. The area of bridges that have not been repaired for 25 or more years makes over $30 \%$.

$>$ The condition of roads has an influence on the safety of car traffic; that is why the implementation of safe traffic measures is very important. It is planned to start forming regional cycle-track nets in suburban areas. Concrete places are appointed for establishing road partitions, pedestrian and cycle-tracks, illumination in some road areas and crossroads of different levels. There are also plans to implement complex measures of traffic organization and improvement (reconstruction of crossroads implementing deceleration/ acceleration zones, safety islands, turning zones, roundabouts, traffic-lights, etc.).

$>$ Asphalting gravelled roads. Among the states belonging to the European Union and those seeking integration according to the density of asphalted roads Lithuania overtakes only Latvia and Romania, so it is necessary to develop the net of asphalted roads. The number of gravelled roads is planned to decrease while the net of asphalted roads should develop. The general aim of the programme of asphalting gravelled roads is the reconstruction of roads of national importance of the Republic of Lithuania with the purpose of reducing social and economic differences between districts and regions.

$>$ Reconstruction of roads which are not international roads will firstly be made in those areas where the requirements of $\mathrm{V}$ category are not satisfied and the covering is weak.

\section{Funding of a road net}

The funding of the Lithuanian road net is based on the Law of Funding Road Handling and Development Programme of the Republic of Lithuania [3], Article 3 of which enumerates the sources of funding:

$>$ Deduction from income;

$>$ Part of excise received from the sold petrol and diesel fuel;

$>$ Excise received from the sold liquid gas for cars;

$>$ Fee of the means of transport for goods registered in the Republic of Lithuania;

$>$ User fee of the owners or possessors of the means of transport registered in the Republic of Lithuania;

$>\quad$ User fee of the owners or possessors of the means of transport registered in foreign countries;

$>$ Fee for driving the roads by the means of transport (their joints) registered in the Republic of Lithuania and foreign countries, the measures of which with loading or without it exceed the legal ones, or if the legal thrust or the general weight 
of the means of transport (their joints) exceeds the allowable;

$>$ Fee of the permit to perform various jobs on the road line or its security zone;

$>$ Funds of State budget;

$>$ Purposive funds of legal and private persons or those of foreign countries.

Since July 1, 2005, the Government of the Republic of Lithuania refuses deduction from income as one of the sources of funding Road Handling and Development Programme (RHDP). It is confirmed by the Law of Endorsement of Financial Indicators of the State Budget and Municipality Budgets of 2005, which projects the reduction of deduction from income in comparison with $230 \mathrm{~m} \mathrm{Lt}$ compared with $437.16 \mathrm{~m} \mathrm{Lt}^{1}$ obtained by the Tax Inspection in the year 2004. When the income charges are abolished, KPPP will not get about $460 \mathrm{~m} \mathrm{Lt}$ in 2006 .

The retraction of this source of income is a positive step as the road fee collected from turnover contradicted the principles of taxing, i.e. it was paid even by companies owning not a single means of transport; besides, there is a number of assumptions to consider the road tax from turnover as contradicting the EU law.

Article 5 of the Law of Funding Road Handling and Development Programme of the Republic of Lithuania [3] projects $40 \%$ excise received from the sold petrol and diesel fuel to be transferred to RHDP account from January 1, 2004, which is by $2 \%$ more than it used to be (38\%). In 2005 the Government of the Republic of Lithuania is going to increase excise received from the sold petrol and diesel fuel and allot RHDP from $40 \%$ to $50 \%$, and in 2006 - up to $60 \%$, aiming to reimburse the loss of RHDP funds. Taking into account that $998.88 \mathrm{~m} \mathrm{Lt}$ of fuel duties ${ }^{2}$ was obtained during eleven months of the year 2004, every additional $10 \%$ of fuel (petrol and diesel oil) duties will increase the financing of KPPP by more than $100 \mathrm{~m}$ Lt. Consequently in 2006 the Government will partially compensate the future $460 \mathrm{~m} \mathrm{Lt}$. decrease of RHDP. It will be in part compensated by duties which will make more than $200 \mathrm{~m} \mathrm{Lt}$. The funding of the Lithuanian Road Handling and Development Programme has been increased in last five years (Fig 1).

One of the recent trends of financing road development is the growing EU support which will reach $93 \mathrm{~m} \mathrm{Lt}$ in 2004. This is $28 \mathrm{~m} \mathrm{Lt}$ more than the amount planned according to the Programme of Maintenance and Development of Major Lithuanian Roads for 20022015. Now (in 2005) we expect to get the EU funds worth $274 \mathrm{~m} \mathrm{Lt}$, while, according to the Programme,

\footnotetext{
${ }^{1}$ The data provided by the Finance Ministry of Lithuania.

2 Note: it is $47.76 \mathrm{~m} \mathrm{Lt}$ more than in the same period in 2003. Source of information: State Tax Inspection of the Finance Ministry.
}

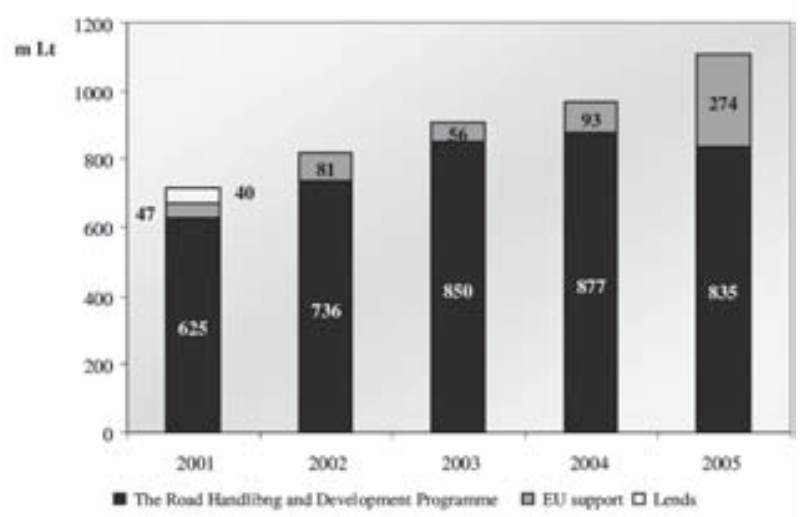

Fig 1. The structure of funding the Lithuanian Road

Handling and Development Programme in 2001-2005 (Provided by the Administration of Motor Roads of Lithuania in the Ministry of Transportation)

this support $(250 \mathrm{~m} \mathrm{Lt})$ was expected to be obtained only in 2010. This year the financing from the EU funds has grown more than threefold compared with that in 2004.

Similar volume of funding should remain in the future. Besides, the anticipated EU funds of this year make approximately one fourth of the whole scope of RHDP funding. Of course, this support is allocated to concrete projects and cannot be used at the discretion of authorized Lithuanian institutions, but having this additional source of income it is possible to redistribute the funds of the Lithuanian budget accordingly.

The Road Handling and Development Programme for the Roads of National Importance specifies that in case of shortage of funds, the funding priorities of road sector should be as follows:

> Road handling and bridge reconstruction in case of emergency condition as well as other required expenses;

$>$ Periodic jobs of road and bridge handling, safe traffic measures;

$>$ Strengthening of covering, asphalting of gravelled roads, road and bridge reconstructions;

Laying of new roads, building of road constructions.

The same priorities can be observed in the financing estimate of the Programme of Road Maintenance and Development in 2004. Last year $231 \mathrm{~m} \mathrm{Lt}$ was allocated to road maintenance and about $181 \mathrm{~m} \mathrm{Lt}$ to road building, upgrading and repair. At the same time, about $28 \mathrm{~m} \mathrm{Lt}$ was allocated to the construction of bridges, viaducts and tunnels ${ }^{3}$.

\footnotetext{
${ }^{3}$ Resolution No 775 of the Lithuanian government on the amendment to resolution No 145 adopted in February 9, 2004 on 'The endorsement of the estimate for financing the Programme of Road Maintenance and Development in 2004' // June 22, 2004, Vilnius.
} 


\section{World experience of road funding}

World experience proves that together with the growing number of cars tax return for funding roads has been increasing as well. However, governments started to control road-financing funds and use their means to cover the expenses of other programmes or budget deficit. The result of such policy of governments is that they not only used the greater part of tax return allocated for roads beside the purpose, but also allocated too little for basic road handling and repair.

Most of the countries in the world see the necessity to modernize a road net, as poor management of a road net causes a great security, economic, social, and environmental price. However, considering this, governments plan to impose car drivers with bigger road taxes or to expand the practical application of the principle "user pays", for instance, charging fees on old highways or entering cities.

FIA (International Automobile Federation Federación Internacional del Automóvil: www.fia.com) and AIT (International Tourism Alliance - Alianza Internacional de Turismo: www.aitgva.ch) have carried out a world opinion poll of automobile organizations, representing more than 100 million car drivers, the generalized result of which could be as follows:

$>$ Seventeen countries from 22 that took part in the poll have a certain highway taxing system implemented - either fees or vignette. The bigger part of the collected money is used for the development of road infrastructure;

$>$ Five countries having no highway taxing system, are: the United Kingdom, Ireland, Holland, New Zealand, and Finland. Germany imposes taxes only on big trucks, not private cars;

$>$ Norway and Singapore impose city-entrance fees;

$>$ Eleven countries from those which now impose a taxing system charging highways and cities, discuss further possibilities of imposing taxes on roads.

Four from five countries, not charging highways, discuss the possibility of imposing direct taxes for using roads.

Aiming to illustrate different experience and practice of countries while directly charging the usage of roads, these countries were distinguished: Singapore, Norway, Germany, and Austria.

Germany. The main source of financing German roads is taxes paid by the users of roads. Only a part of this budget collected by fees is used for funding roads. Nevertheless, since January 1, 2005, a new satellite road charging system works in Germany. More than 300 thousand of trucks has small computers equipped, allowing to observe moving of those cars via satellite, the data of which are transferred to the main computer with the help of mobile connection. Drivers of other trucks have to pay the fee via Internet or tax-machines. Drivers of cars and other means of transport weighing less than 12 tons are not obliged to pay the fee.

The biggest automated system in the world of paying for driving roads has been implemented sixteen months later than planned. Software and organizational problems conditioned the delay. The concern employed 2,5 thousand of people who will help drivers to accustom to the new order.

The greater part of the tax return, which approximately makes $0,124 \mathrm{EUR} / \mathrm{km}$, is going to be allocated to the renovation of highways. The German Government also expects that the fee will encourage a more intensive transportation of loadings via railways.

Austria. Since January 1, 2004, an electronic road taxing system has been implemented in Austria, although legal acts regulating it were approved already in 1996. This system charges all trucks, the general weight of which is bigger than 3,5 tons, according to their mileage. The law of 1996 indicated that cars should be charged, too, though this provision has been later rejected. The implementation of an electronic road charging system was delayed due to the resistance of citizens. Having implemented this system Austrian road infrastructure is charged with the largest fees in the European Union, much larger than, for instance, in Germany. It is done with the purpose of limiting transit transport streams via Austrian territory, as their growing scope causes big ecological and social losses. Two-axle truck pays 0,130 Euro/km, three-axle truck - 0,182 Euro/km, and four and more axles - 0,273 Euro/km.

Singapore. A new electronic road charging system was implemented in Singapore in 1999. It changed the "paper system" which has been working since 1975. The electronic system applies alternate taxing when the size of a fee depends on the intensity of traffic the system helps to avoid traffic jams. The fees grow when the intensity of road traffic increases and becomes smaller when the intensity of traffic decreases. The citizens of Singapore favoured the system as its implementation reduced the tax for the owners of the means of transport by the sum bigger than the new expenses on road fees. The level of traffic jams remained the same as the automobilisation rate grew.

Norway. Norway has taxing roundabouts outside cities. The return collected in Oslo is allocated to road net funding in the first place. A part of these funds goes to traffic management and public transport projects. The applied fixed 24-hour fees are created not with the purpose of regulating traffic intensity, but for generating income. Norway Automobile Driv- 
ers Organization has neglectfully accepted these taxing systems and only in such cases when they conditioned a faster development of roads and when citizens' support was received. This country obliged to withdraw the charges after carrying out projects however, these obligations were not always observed. The Government of Norway announced the intentions to differentiate the fees according to the time in Oslo and other cities' roundabouts, however, the collected income would not be used for transport protects, but for the compensation of external transport outcomes. Such arguments have not persuaded the society to support the initiative.

\section{Estimation of investments for $1 \mathrm{~km}$ of road}

Handling and repair work of car roads is financed by Special Road Handling and Development Programme and the European Union funds. According to the Law of Funding Road Handling and Development Programme of the Republic of Lithuania [3], these funds are distributed in the following way: $75 \%$ to financing of roads of national importance, $20 \%$ to laying, repairing and handling of local municipality roads, national forest, national park roads and streets, $5 \%$ to financing of other state needs related to roads.

Is this ratio correct? Additional researches should be organized aimed at finding it out, related to the efficiency of using the allocated funds, i.e. it is necessary to determine which sector, (with the exception of the most important urgent work necessary for the safety of traffic), the efficiency of the used funds, the period of their buy-off in accordance with clearly specified criteria like thrust, throughput, better ratio coefficient as well as the increased traffic safety, etc.

Projecting investment in separate road zones is not an easy task as it is essential to estimate an average weight coefficient of restoration (repair) or new laying of $1 \mathrm{~km}$ of road which should measure the conformation of an area (subgrades, cuttings), the number of bridges and overbridges as well as the prices of their construction and repair, the number of access (off-going) roads together with their projected and safe traffic particularities, etc. [4].

Comparative index might express what assignations have been allocated to one road kilometre:

$$
C_{\text {lyg. }}=\sum C_{i} / \sum L_{i}, € / \mathrm{km},
$$

here $\sum C_{i}$-sum of related investments allocated to performing certain work;

$\sum L_{i}$ - total stretch of the length of roads in which these funds are invested.

Considering that:
$C_{1}$ - funds for financing of roads of national importance, $€$,

$C_{2}$ - funds for financing of laying, repairing and handling local municipality roads, national forest, national park roads and streets, $€$,

$C_{3}$ - funds for financing of other needs related to roads, $€$.

Then the comparative indexes, i.e. average funds allocated to one road kilometre could be written in the following order:

$$
\begin{aligned}
& C_{\text {comp }}^{\prime}=C_{1} / L_{1}, € / \mathrm{km}, \\
& C_{\text {comp }}^{\prime \prime}=C_{2} / L_{2}, € / \mathrm{km}, \\
& C_{\text {comp }}^{\prime \prime \prime}=C_{3} / L_{1}+L_{2}, € / \mathrm{km} .
\end{aligned}
$$

Values of $C_{\text {comp }}^{\prime}, C_{\text {comp }}^{\prime \prime}$ and $C_{\text {comp }}^{\prime \prime \prime}$ are presented in Table.

Analyzing the data provided in the Table and Fig 2, it is noticeable that investments in roads of national importance for one road kilometre have slightly increased in 2004, comparing with the year of 2003; the same tendency remains in the case of roads of local importance as well as funds allocated for other State needs related to roads. In 2005, a very small reduction of investments is noticeable at all points.

Table. The estimations according to (2), (3), and (4) formulas [5]

\begin{tabular}{|l|c|c|c|}
\hline Years & $\mathrm{C}^{\prime}, € / \mathrm{km}$ & $\mathrm{C}^{\prime \prime}, € / \mathrm{km}$ & $\mathrm{C}^{\prime \prime}, € / \mathrm{km}$ \\
\hline 2003 & 7948 & 778 & 142 \\
\hline 2004 & 8457 & 828 & 151 \\
\hline 2005 & 8455 & 818 & 150 \\
\hline
\end{tabular}

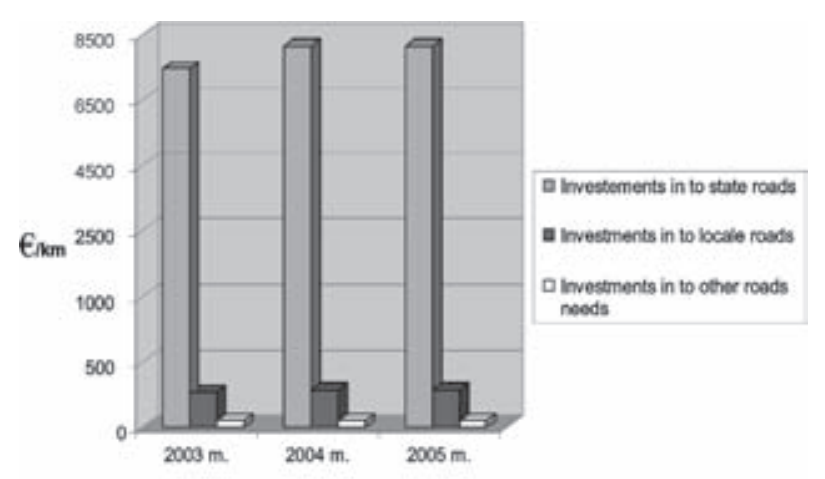

Fig 2. Distribution of investments in a road network 


\section{Conclusions}

1. When the government abolished income charge as one of the major sources of financing the Programme of Road Maintenance and Development, no disagreement with common charging principles has been left. This means that an enterprise not owning any transport facilities is free from a road tax.

2. This year the Lithuanian government is going to increase the percentage of duties enforced on petrol and diesel oil from 40 to $50 \%$. Every extra $10 \%$ of duties for fuel (petrol and diesel oil) will increase the financing of the Programme of Road Maintenance and Development by more than $100 \mathrm{~m} \mathrm{Lt}$. This implies that the government will compensate the decrease of funds intended for the above Programme financing partly by duty payment.

3. Summing up these remarks, when the total length of roads practically does not change, it is possible to conclude that investments according to the different points $C_{1}, C_{2}, C_{3}$ in roads depend only on the general amount allocated during past years, i.e. they are divided by the same ratio without considering the efficiency of the allocated funds according to separate points. Nevertheless, with such big investments the condition of the present road net changes every year.

4. Further continuation of this work would be estimation of weight coefficients for $1 \mathrm{~km}$ of road (in accordance with certain categories), which would measure the efficiency of the allocated funds according to the parameters of the exploitation of amount and environment and considering that to estimate the distribution of the financial streams. Such methodology would give the biggest economic effect.

\section{References}

1. Substantiation of road maintenance and developing program of year 2005-2007 (Kelių priežiūros ir plètros programos pagrindimas 2005-2007 m.), SE "Institute of Transport and Road researches”, Kaunas, 2005 (in Lithuanian).

2. Road maintenance and developing program of year 2003, 2004, 2005 (Project) (2003, 2004, 2005 metų Kelių priežiūros ir plètros programa (projektas)), Lithuanian Road Administration under Ministry of Transport and Communications , Vilnius, 2005 (in Lithuanian).

3. Financing law of road maintenance and developing program of Republic of Lithuania (Lietuvos Respublikos Kelių priežiūros ir plètros programos finansavimo įstatymas), // Žin., 2000, Nr. 92-2873, 2001, Nr. 112-4089, 2004, Nr. 171-6302 (in Lithuanian).

4. Kancerevičius, G. Finance and investment (Finansai ir investicijos). Kaunas: JSC „Smaltijos leidykla”, 2004 (in Lithuanian).

5. Limba, R., Fadina, O. Determining of vehicle capacity based on a lot size of goods. Transport, Vol XIX, No 2, 2004, p. 92-95. 